\title{
Policy and Practice in Education Reform in Mongolia and Uzbekistan during the First Two Decades of the Post-Soviet Era
}

\author{
John C. Weidman ${ }^{\mathrm{a},{ }^{*}}$ and Brian Yoder ${ }^{\mathrm{b}}$ \\ ${ }^{a}$ University of Pittsburgh, USA \\ ${ }^{\mathrm{b}}$ National Aeronautics and Space Administration, USA
}

\begin{abstract}
This article describes the social, economic, and political processes that have influenced educational reform in two countries of Central Asia since the fall of the Soviet Union in 1991. It compares and contrasts the various educational reform initiatives that have occurred in each country, including legal and policy frameworks, curriculum change, decentralization, privatization, finance, structure, and emphasis of educational systems, and the fit between what is taught in educational institutions and demands of the labor market. A sector-wide framework for education reform is presented to facilitate understanding of the very complex set of processes involved.
\end{abstract}

\begin{abstract}
Abstrak
Artikel ini mendiskusikan perkembangan politik, ekonomi dan sosial yang mempengaruhi reformasi pendidikan di dua negara di Asia Tengah sejak keruntuhan Uni Soviet tahun 1991. Penulis membandingkan berbagai initiative reformasi pendidikan yang terjadi di masing-nasing negara termasuk dasar kebijakan dan hukum, perubahan kurikulum, desentralisasi, privatisasi, keuangan, struktur dan penekanan pada sistem pendidikan, termasuk kesesuaian antara materi yang diajarkan di institusi pendidikan dengan tuntutan pasar tenaga kerja. Artikel ini juga memaparkan dasar reformasi pendididkan di beberapa sektor untuk lebih memahami kompleksitas proses perubahan yang terjadi.
\end{abstract}

Key Words: Policy Reform, Decentralization, Privatization, Mongolia, Uzbekistan

\section{Introduction}

With the sudden breakup of the Soviet Union in December of 1991, the former Soviet Republics of Central Asia were forced to cope with the substantial social and economic burdens that accompanied independence. Many observers from the West assumed that the former Soviet Republics of Central Asia would be able to transition rapidly from single-party governments with command economies into democracies with international market economies. Revenues from investment and privatization of government assets would offset short-term economic shocks of removing price controls and increased earnings from private ownership of enterprises would enable "structural adjustments"

*Corresponding author. Address: Department of Administrative and Policy Studies, School of Education, University of Pittsburgh, 5910 Wesley W. Posvar Hall, Pittsburgh, PA, USA.

Email: weidman@pitt.edu. that shifted responsibility for payment of social services, including education, at least partially from the government to citizens (Dawisha and Parrott 1997).

This article explores the educational policy reforms that occurred during the first decade of transition in the Central Asian countries of Mongolia and Uzbekistan and describes how they have been carried into the first decade of the twenty-first century. Uzbekistan was formerly part of the USSR. Mongolia, while maintaining its independence, was nonetheless strongly influenced politically and highly dependent economically (a third of its GDP provided by the Soviet Union) on its neighbor to the north (Weidman and Bat-Erdene 2002). With respect to education, both countries had Soviet-style educational systems with highly specialized curricula designed to prepare students for jobs in a command economy.

The analysis of the first post-transition decade is based primarily on a review of case studies on national education reform between 1990 and 2000 in Mongolia and Uzbekistan that were 
prepared as part of Asian Development Bank (ADB) Regional Technical Assistance (RETA) Project No. 5946-REG: Subregional Cooperation in Managing Education Reforms (Batrinchin et al. 2002; Seitkhalilov et al. 2002; ADB 2004). While most information available on post-totalitarian educational transition is based on descriptive case studies of a single country (Polyzoi, Fullan and Anchan 2003), this paper compares and contrasts the experiences in two countries with related historical and political contexts.

While both countries endorsed values of democracy and market economics in the immediate post-transition years, each has taken a different path, with Mongolia progressing in a democratic, market-oriented direction while Uzbekistan remains centralized and authoritarian with limited progress toward economic reform. It could, in fact, be argued that the education reform process in both countries mirror, to a large extent, the government and economic systems that have developed since 1991.

\section{Country Contexts and Transitions}

Uzbekistan covers a geographical area of 447,400 square kilometers (slightly larger than California), but it has the largest population in Central Asia with almost 28 million people. Uzbekistan is ethnically diverse, with Uzbek (80 percent) the largest group, followed by Russian (5.5 percent), Tajik (5 percent), Kazakh (3 percent), Karakalpak (2.5 percent), Tatar (1.5 percent), and 2.5 percent of other origins. Religiously, Uzbekistan is primarily Muslim (88 percent, mostly Sunni), with Eastern Orthodox (9 percent) the next largest religious group. Uzbekistan is predominantly rural with just over a third (37 percnent) of the population living in urban areas (CIA 2010b).

Uzbekistan did not exist as a political entity prior to the 1920 s when the Soviet Union created the Republic of Uzbekistan from parts of Turkestan, the Bukharan Amirate, and the Khivan Khanate (Dawisha and Parrott 1997). Its one-party, hierarchical political structure and administrative system was similar to those in the other republics of the USSR (Pomfret and Anderson 1997). Despite its efforts in the early 1990 s to transition to a marketoriented democracy, Uzbekistan continues under "authoritarian presidential rule, with little power outside the executive branch" (CIA 2010b), and has been very slow in implementing economic reforms.

Two interpretations of politics in Uzbekistan over the last decade can be found in the literature. One interpretation comes from government sources inside Uzbekistan, principally President Karimov and his "aparat," and presents its authoritarianism as a necessary part of a slow transition from a single-party government and centralized command economy into a liberal democracy and free market economy (Karimov 1998; Center for Economic Research 1997). According to this line of reasoning, it is necessary to have centrally-controlled and slow political and economic transition in order to prevent economic instability and social conflict, particularly the spread of civil war between ethnic and fanatical religious groups.

The other interpretation comes from sources outside Uzbekistan, arguing that political elites in Uzbekistan are using the threat of ethnic violence and the spread of civil war to maintain power (Freedom House 2009; Dawisha and Parrott 1997; Peimani 2002). Regardless of the interpretation of recent developments in Uzbekistan, political leaders have resisted implementing a full transition from a single-party political system and government-managed economy.

Mongolia is about three times the size of Uzbekistan with 1,565,000 square kilometers (slightly smaller than Alaska) but has just 10 percent of the population with 3.1 million people (CIA 2010a). Ethnically, 95 percent of Mongolia's population is Mongol (mostly Khalkha) and 5 percent is Turkic (mostly Kazakh). Religiously, 96 percent of Mongolians are Tibetan Buddhist Lamaists and 4 percnet are Muslim, Shamanist, or Christian). More than half (57 percnet) of Mongolia's population lives in the capital city, Ulaanbaatar (CIA 2010a).

Mongolia gained independence from China in 1921 with the help of the USSR. From 1921 to 1924 it was a constitutional monarchy until the death of Mongolia's first and only priest-king, the Bogd Khan. In 1924 the Mongolia People's Revolutionary Party (MPRP) assumed power and launched the country on the path of socialism following the Soviet model of development (ADB 1992). While not part of the USSR, Mongolia was closely aligned, both politically and economically, with the USSR providing a third of Mongolia's GDP (Weidman et al. 1997).

Mongolia has seen a number of democratic political party changes since the breakup of the Soviet Union in 1991. The MPRP won the first democratic election held in 1992. In 1996 the MPRP lost to the Democratic Union Coalition (DUC), which put forward a number of key reforms to modernize the economy and further democratize the political system. The DUC lost to the MPRP in 2000. The MPRP continued many of the reforms of the DUC, continuing the focus on issues of social welfare (CIA 2010a). However, it also pulled back on efforts to decentralize government services.

Prior to the break-up of the Soviet Union education, health services and social support services were provided free of charge by the state in both Mongolia and Uzbekistan. A combination of cuts in social spending from the Soviet Union to the Soviet Republics and Mongolia in the late 1980s to early 1990s, hyperinflation during the mid-1990s, and reduced economic 
output due to changes in economic structure greatly reduced the amount of money available for social spending. Following the break-up of the Soviet Union, states could not continue to finance all social services, and the quality and access to social services was reduced, especially for lower income families with young children and people living in rural areas (Weidman et al. 2003).

\section{Education Policy Supporting Liberal Democracy and Market Economy}

In both Mongolia and Uzbekistan, there was early, posttransition support for liberal democracy and economic market reforms within their countries that influenced education reform. For example, in Uzbekistan:

The principle factors driving the need for change in the education system are: the transition from a command to a market economy ensuring genuine economic independence of the Republic; redirection of the economy from production of manufactured goods; the development of a strong democratic state and civil society, eliminating social conflicts among citizens while developing their intellectual potential, a sense of pride in their country, respect for its cultural and high traditions and intellectual heritage; the promoting of education as a priority in national social policy; the development of the protection and improvement of the environment, and integration of the Republic into the international community. (Seitkhalilov et al. 2002, 2)

In effect, Mongolia seems to have taken a similar approach, though the outcomes have been quite different:

Just over a decade has passed since the market economy reform process started in Mongolia in 1990. By adopting a new Constitution in 1992, Mongolians have aspired to the objective of building a humane, civil and democratic society and have commenced reforms in politics, economy and society. The Mongolian economy was in an extremely difficult situation at the beginning of the 1990s when the Government initiated a process of economic liberalization with substantial backing from the international community. Since then, the country has become more open politically and economically and the legal foundation for a private sector led market economy has been established. (Batrinchin et al. 2002, 1)

Both countries claim to have made a political and economic transition from a single party government and command economy to a liberal democracy and market economy, much like many outside observers from the West assumed would happen. Concurrent social and educational transitions have also occurred. In education, this is reflected in efforts to change from centralized control, teacher-centered instruction and planned manpower supply driven systems to more decentralized control, studentcentered instruction, and student and labor market demand driven systems (Weidman et al. 1977).

Mongolia has, however, arguably been more successful in accomplishing these transitions. While starting at roughly the same pre-transition level of economic development in $1990(2,271$ per capita purchasing power parity (PPP) in constant 2005 international \$ for Mongolia versus 2,002 per capita PPP in constant 2005 international $\$$ for Uzbekistan), by 2008, Mongolia's per capita PPP in constant 2005 international \$ had grown to 3,286 while the comparable figure for Uzbekistan was just 2,455 (World Bank 2010). With respect to politics, Mongolia has had several changes in the ruling party since 1991 but, 20 years later, Uzbekistan still has the same President (Islam Karimov).

Mongolia and Uzbekistan had very different processes of educational reform during the 1990s, though the processes of education reform mirror what is occurring in the political systems of each country. Mongolia has decentralized its educational system and has had more of a participatory approach to education reform; while Uzbekistan has remained strongly centralized had has had more of a top-down approach to education reform, as its political system has remained strongly authoritarian. Table 1 compares several key elements of policy reform in the two countries.

Immediately after the fall of the Soviet Union in 1991, Mongolia's education reform process was centralized and topdown; but in 1995, a legislative framework was developed to introduce democratic mechanisms, decentralize administratively, and improve independent activity of local administrations and educational institutions. Due to these changes, the role of the Ministry of Education, Science and Culture shifted away from direct day-to-day decision-making related to education institutions to more of a policy and strategy-planning agency with the duties of providing leadership, coordination, monitoring and evaluation.

The hierarchical structure of education administration in Mongolia has been flattened. The powers and rights of educational institutions were expanded to allow for more institutional innovation. Educational institutions have become more concerned with developing and formulating their own missions, goals and objectives. This has contributed to more bottom-up and participatory educational reforms in Mongolia (Batrinchin et al. 2002). In contrast, Uzbekistan's educational reform process has been very centralized. The principle vehicle 
Table 1. Comparison of Education Reform since 1991: Uzbekistan and Mongolia

\begin{tabular}{|c|c|c|}
\hline Components of Reform & Uzbekistan & Mongolia \\
\hline \multicolumn{3}{|l|}{ Enabling Elements } \\
\hline Legal Framework & \multicolumn{2}{|c|}{ Constitution and Education Laws } \\
\hline Policy Framework & National Program on Personnel Training (1997) & $\begin{array}{l}\text { Education and Human Resource Development } \\
\text { Master Plan (1994); } \\
\text { National Programs on Pre-School Education } \\
\text { (1995) and Technical Education and Vocational } \\
\text { Training (1998) }\end{array}$ \\
\hline \multicolumn{3}{|l|}{ Implementation } \\
\hline Orientation & \multicolumn{2}{|c|}{$\begin{array}{l}\text { Orient education to national policy and development needs, } \\
\text { especially transition to a market economy }\end{array}$} \\
\hline Content & \multicolumn{2}{|c|}{ Curriculum reform, publication of textbooks } \\
\hline Type Script of Texts & Change from Cyrillic to Latin & $\begin{array}{l}\text { Initial change from Cyrillic to traditional } \\
\text { Mongolian script, then back to Cyrillic }\end{array}$ \\
\hline Teacher Preparation & \multicolumn{2}{|c|}{ Pre-service and in-service training of teachers } \\
\hline Information Technology & Emphasized primary and secondary schools & Emphasized higher education \\
\hline Privatization & Virtually none as of 2001 & $\begin{array}{l}\text { More than } 33 \text { percent of higher education } \\
\text { students enrolled in private institutions }\end{array}$ \\
\hline Organizational Structure & \multicolumn{2}{|c|}{ Increased decentralization } \\
\hline Years of School & $\begin{array}{l}\text { Increase from } 11 \text { to } 12 \text { year primary and } \\
\text { secondary: } 9+3 \text { (specialized professional or } \\
\text { academic) }\end{array}$ & $\begin{array}{l}\text { Increase from } 10 \text { to } 12 \text { year primary and } \\
\text { secondary: } 8+4 \text { (specialized or academic) }\end{array}$ \\
\hline Ministry Control of Higher Education & $\begin{array}{l}\text { Several higher education institutions under } \\
\text { direct non-education Ministry control }\end{array}$ & $\begin{array}{l}\text { Only Military University not under Education } \\
\text { Ministry }\end{array}$ \\
\hline Fees & $\begin{array}{l}\text { None in primary/secondary, limited in higher } \\
\text { education }\end{array}$ & $\begin{array}{l}\text { None in primary/secondary, full fees in higher } \\
\text { education }\end{array}$ \\
\hline Government Education Expenditure & $\begin{array}{l}\text { Reduced from } 9 \text { percent to less than } 7 \text { percent of } \\
\text { GDP }\end{array}$ & Reduced from 6 percent to 5 percent of GDP \\
\hline Fit of Training to Labor Market Demand & \multicolumn{2}{|c|}{$\begin{array}{l}\text { Poor due to limited data about emerging labor market; } \\
\text { lack of up-to-date training programs and equipment }\end{array}$} \\
\hline
\end{tabular}

for education reform has been the National Program of Personnel Training (NPPT), which was created in 1996 through decrees of the President and resolutions of the Cabinet of Ministers. The NPPT is a comprehensive plan of reform for all aspects of the Uzbekistan

\section{Enabling Elements—Laws and Policy Documents}

The structure of Uzbekistan's and Mongolia's enabling elements for education: laws and educational policies are similar. Both Mongolia and Uzbekistan passed laws on education in the early 1990s, which provided a broad legal framework for educational reform. Both Mongolia and Uzbekistan passed subsequent laws for education reform in more specific areas of education. Both counties implemented education reforms in stages. While Mongolia and Uzbekistan have a similar sequence to education laws and reforms, it is important to note that the substance of the laws and how they were developed were very different. Uzbekistan's education laws are primarily decrees from the president while Mongolia's education laws are largely based on a sector analysis of the state of education in Mongolia and master plan involving a broad range of stakeholders that was funded by the ADB in 1993 and 1994 (ADB 2004; Weidman 2001).

Similar to Uzbekistan's political and economic reform processes, the creation of educational laws and the stages of reform have been very centralized. Uzbekistan's first Law on Education was passed in 1992 and formed the basis for the subsequent educational reform efforts, the NPPT in 1996. The basic goals the NPPT are: 
to ensure that the education process responds to the personal interests, legislative needs and organizational, psychological and pedagogical conditions necessary for the formation of national culture; (b) to adapt the attitudes of society towards the choice of individuals to study in subsequent educational and professional programs; and (c) to help to develop today's citizens so that they are aware of their responsibilities to the state, society and their families. (Seitkhalilov et al. 2002, 7)

The NPPT formed the central vehicle for educational reforms, but all initiatives emanated from the president's office. No specific evidence is given in the country case study about which reforms were successful, though most are presumed to be progressing as expected.

According to the document, the goals of the NPPT would be achieved through the following educational reforms:

1. A competitive environment for teachers and personnel training would be created through the development of an integrated educational scientific and productive system consisting of government and private schools.

2. Education contents would be updated to include contemporary scientific, technological and cultural advances; and tied to the political and economic conditions of the country.

3. Stronger links would be created between education and the development of democracy and civil society.

4. Teacher in-service training would be improved and increase the social status of teaching as a profession would be increased.

5. Licensing and accreditation standards for schools and standards for teacher training would be created.

6. Character education called "spiritual and moral learning" would be developed.

7. Funding for education would be diversified, including increasing foreign investment.

8. International cooperation in the field of personnel training would be developed.

The NPPT was to be implemented in three stages. Stage One (1997-2001) was to create a legal, personnel, scientificmethodological and financial conditions for reforms while preserving pre-existing aspects of the educational system that were working well, although the country case study does not specify what aspects of the educational system was preserved. To use the language from the country case study, during this stage, Uzbekistan was to restructure the contents of continuous education; develop and introduce new training and methodological complexes; prepare the necessary material, technical, methodological and personnel basis for secondary specialized vocational education; and develop and introduce a common rating system for the evaluation of education institution, and develop a system for monitoring the quality of personnel training.

Stage Two (2001-2005) was to be a full-scale implementation of the NPPT, with adjustments to the educational system based on experience and changes in the labor market and socio-economic conditions. During this stage one year was added to basic education to make nine years of primary education and three years of secondary education where students are tracked into general secondary education, specialized education or vocational secondary education. Students also have the choice to drop out of school after Grade 9. Schools are supposed to have qualified teachers by this time. Also, educational activities are supposed to be strengthened by quality academic literature and good pedagogical techniques with the dissemination of quality academic literature though local and state information networks.

Stage Three (2005 and further on) involves continuous improvement and development of the educational system based on experience and changes in the economic and socio-economic conditions in the country. This stage includes the consolidation of resources and personnel to insure a supply of the most up-to-date methodological materials and information technologies. Also included in Stage Three are the development of national elite educational institutions and the development of computer networks within schools with access to the World Wide Web (Seitkhalilov et al. 2002).

The development of education laws and reform in Uzbekistan has been very centralized and regulated. The government has not allowed civil society to develop (Dawisha and Parrott 1997), which could have played a role in the development of institutions outside the government that could contribute to more participatory education reforms.

Uzbekistan's centralized and regulated process is in sharp contrast to Mongolia's more decentralized reforms. The first education law in Mongolia, the Mongolian Peoples Republic Education Law, was passed in 1991, prior to the passing of the constitution. This laid the legal foundation for the decentralization of education, the establishment of private educational institutions, and the creation of legal conditions to "demolish" the old educational structure (Batrinchin et al. 2002).

Mongolia conducted a systematic study of the education sector in the early 1990s and based on the study developed a subsequent education master plan. This was done through the ADB Sector Review called the Mongolian Education and Human Resource 
Sector Review 1993, and a master plan for the education sector called Mongolia Education and Human Resource Master Plan 1994. The Sector Review 1993 described the educational system at that time and identified pressing concerns. The 1994 Master Plan was developed on the sector review and identified the following areas for immediate action: enhancement of basic and general education, reform higher education for development purposes, rationalize vocational education, provisions for learning opportunities for out-of-school youth, improve education management, and improve efficiency in the Ministry of Science and Education.

Mongolia passed a series of laws in 1995, beginning with the Mongolian Government Education Policy that addressed ways for Mongolia to overcome their short-term crisis in education while maintaining development, and create a new educational system that would facilitate the growth of intellectual factors that would help develop transitioning Mongolia. The Education Law of 1995 reinforced educational decentralization; and legalized the rights of school boards to approve school charters, rules, regulations, structures, personnel and annual budgets. The Primary and Secondary Education Law reformulated the objectives of preschool, primary and secondary education and legalized standard requirements for educational content, forms of providers, duration, and organizational structure; and incorporated vocational and technical training into secondary education. The Higher Education Law legalized the credit planning system, so that students could plan their own course of studies; created an accreditation system in higher education; created degrees that conformed to international requirements (i.e., Bachelors, Masters, and Doctorate).

Mongolia's educational reforms and phases of education reform are based on systematically gathered information on the state of education in Mongolia a few years after beginning the process of transition. Phase One (1991-1994) was implemented as the formulation of the educational reform agenda. This included the creation of a legal basis for educational reform in the form of Mongolian People's Republic Education Law, subsequently followed by the Sector Review 1993 the 1994 Master Plan which formed the basis for direction of educational reform in basic and general education in the mid-1990s.

Phase Two (1995-2000) was to stabilize the educational reform process (education ahead of other sectors) and develop and adopt educational programs. The most important national programs for the structure of education in Mongolia included the National Program for Preschool Education, National Program for Non-formal Education, National Program for Technical Education and Vocational Training, and National Program for Mongolian Script. The National Program for Preschool Education was to address the significantly reduced number of day nursery kindergartens in the countryside because of lack of funds due to financial decentralization of funding for education in the early 1990s. The program was aimed at developing a pre-school education structure appropriate for both nomadic and sedentary populations and at strengthening the skills of pre-school educators to meet modern requirements.

The National Program for Non-formal Education was meant to provide education to the population outside of formal schooling through the establishment of non-formal education centers throughout the country. The main objectives were to improve the literacy rate, up grade the level of education of this population, provide professional and labor related training, and assist people to acquire the skills and attitudes necessary for self-study.

During the early 1990s, technical and vocational education declined due to lack of employment opportunities. The National Program for Technical Education and Vocational Training and National was to restructure and improve the management and organizational structure of technical education and vocational training (TEVT), renovate and re-equip training facilities, development multifarious and flexible curricula, and improve access to TEVT. The Program for Mongolian Script was approved in 1995 during a wave of nationalism to re-introduce traditional Mongolian Script in schools.

Phase Three (2000-2005) is based on a review of plans for development in education and human resources in early 1999. Altogether, 23 strategies were documented in a report in which priorities of strategies were proposed as well as estimated costs of implementation. Information from the 1993 sector review was updated to develop strategies from management, pre-school education, primary and secondary education, technical education, higher education and non-formal and distance education (Batrinchin et al. 2002).

The central purpose of secondary school in Mongolia is to develop individuals' scientific and technical knowledge in line with their individual interests and to teach students job skills needed in the local community. The need for technical education and vocational training (TEVT) declined in the early 1990s. As a result, TEVT has been revised to meet the needs to newly developing privatized small and medium sized enterprises (Batrinchin et al. 2002). A recent initiative funded by the American Millennium Challenge Corporation is focusing on improving the vocational and technical education system.

Uzbekistan added three years of compulsory specialized, vocational education (SSVE). After graduating from General Secondary Education (GSE), Grades 1-9, students may go into an academic lyceum or professional college. Academic lyceums are oriented to subject matter in the disciplines, while professional 
colleges provide vocational and technical education. Uzbekistan's plan to build and refurbish existing institutions by the year 2005 into a network of 1,611 professional colleges and 181 academic lyceums has not been accomplished by 2010 .

The aim of SSVE is to develop individuals who are capable of adapting quickly to technological innovations, and the market economy; and are loyal to the principles of democratic and national independence. Graduates of SSVE are awarded a diploma, which indicates their academic specialization (if graduating from a lyceum) or their professional specialization (if graduating from a professional college). Graduates may go to the next stage of education, or may start employment immediately in their area of specialization.

\section{Higher Education}

Mongolia decentralized higher education and reduced budget allocations to higher education beginning in 1993. Institutions of higher education have begun charging fees. Many universities have begun to offer programs in languages, mathematics, humanities, business, accounting and law. Mongolia has implemented a credit system in higher education, so students have more flexibility in choosing their own course of study and can change majors while in university, but this reform seems to have only changed classes to multiple credits and the same inflexible structure for higher education seems to remain.

Mongolia has allowed privately owned institutions of higher education to develop. In 2000, 78 percent of the 172 higher education institutions were privately owned, enrolling 33 percent of the student population. The quality of some private and public institutions remains low, but the country case study points out, these institutions accommodate a certain portion of the population who otherwise could have been left without future training and definitely without a job. The government intends to secure the quality of education in the future through licensing (Batrinchin et al. 2002).

In Uzbekistan, the Ministry of Higher and Secondary Specialized Education (MHSSE) has several levels of control (i.e., methodology, licensing, retraining personnel) over all institutions of higher education, but accountability is dual and even triple. Like the Soviet era, institutions of higher education can be accountable to more than one ministry or state committee. In total, colleges and universities are accountable to more than 20 different ministries and state committees. This arrangement encourages duplication of function and effort and limits the capacity of the MHSSE to manage the system strategically (Seitkhalilov et al. 2002).

\section{Teacher Training}

The primary purpose for teacher training reform for kindergarten, elementary and secondary school teachers in Mongolia is to provide competent lecturers and teachers, and most importantly, to implement the new national curriculum. To reach these teacher training objectives, Mongolia will need to reform the legislative, economic, organizational and managerial structures of teacher training and retraining with international donor money. Reform of teacher training content and methodology began in 2002, and as a result teachers and school managers are starting to show more initiative and willingness to implement education content and standards effectively and have become active in curriculum, textbook and training manual development.

The Mongolian government has decentralized in-service teacher training through the use of vouchers. Teachers are provided with vouchers so they can choose from among various programs offered by different local and central training providers. As of 2002, the voucher program and coordination of the training programs was being administered by the local Education and Culture Center, but future plans are to give administrative responsibility to the schools. The voucher in-service teacher training reform is meant to allow schools to be able to choose the type of teacher training that best fits their needs (Batrinchin et al. 2002).

Improving the quality of teachers in professional colleges and academic lyceums was also emphasized in Uzbekistan, partly through training and partly through incentives. In 2000, the Cabinet of Ministers raised teacher salaries in professional colleges and academic lyceums by an average of 40 percent to motivate existing teachers and to attract new teachers with higher qualifications. In 1999, Higher Education Institutions began training technical and pedagogical staff for professional colleges and academic lyceums in 89 fields of Bachelors degree studies. 9,000 students are enrolled annually. A total of 38 specialized centers for professional development have been established in all parts of the country and 14,900 teachers had training in these centers from 1999 to 2002 . The Ustoz Foundation was established in the capital of Uzbekistan, Tashkent, where over 2,100 teachers underwent retraining in 1999-2000. Also through the Ustoz Foundation, 400 teachers were sent for training overseas in Canada, France, Germany, South Korea, the United Kingdom, and the United States (Seitkhalilov et al. 2002). 


\section{School Curriculum Reforms}

A key element in Mongolian curriculum reform was an effort to create conditions that were favorable for independent learning. The emphasis was on making primary, secondary and higher education curricula consistent with international standards, though no explanation was given for which international standards were referenced. Curriculum remained, however, centralized at the national level (Batrinchin et al. 2002).

Uzbekistan has continued to centralize curriculum at all levels of the education system. In 1999 the Cabinet of Ministers approved the state education standards (SES) for general secondary education in Grades 1-9. The SES for general secondary education incorporates a modern basic study plan, education standards for 23 subjects, standard curricula and training programs. The standards are in compliance with Uzbekistan's main education policy framework known as the National Program of Personnel Training (NPPT). To disseminate information about the SES, all educational institutions have been provided with documents explaining the new regulations, procedures and state standards.

In 2000 the Cabinet of Ministers approved state standards for secondary specialized vocational education, which standardized the educational content across secondary specialized vocational schools and the standardization of 20 general subjects. Also included in this reform effort was the testing of 211 curricula, over 3000 training programs in special subjects in 58 professional colleges and 4 specializations in academic lyceums (Seitkhalilov et al. 2002).

\section{Reforms to the Structure of Education}

Both Uzbekistan and Mongolia made changes to the structure to their education system in the number of years for different levels of education. Uzbekistan, which was heavily influenced by the Soviet Model of education, promulgated a law in 1998 to change its structure from a $4+5+2$ system to a $4+5+3$ system (Seitkhalilov et al. 2002). While Uzbekistan now has a policy promulgating 12 years of compulsory education, as of 2010, it has not been implemented. Secondary Specialized and Vocational Technical education, remnants of the Soviet Model were phased out in 1998 and replaced with three years of Academic Lyceum and Professional College. The Uzbekistan government expected ten percent of all students graduating from Grade 9 to go into the more academic oriented Academic Lyceum, and 90 percent of all students graduating from Grade 9 to go into the more technically and vocationally oriented Professional Colleges (ADB 2004).
The Mongolia education system was also modified in structure and two years added by lowering the age at which children start school from 8 to 7 in 2005 and to 6 in 2010. Hence, rather than adding to the end of secondary school, basic education was expanded by adding two years at the beginning of primary school. Both Mongolia and Uzbekistan have remained financially committed to education throughout the 1990s. Spending on education as a percentage of GDP declined in Uzbekistan from 9 percent to 7 percent from 1990 to 1995 , while education increased from 20 percent to 23 percent of total government expenditures (World Bank, 2010). In the same period, Mongolian education decreased from 18 percent to 17 percent of total government expenditures (World Bank, 2010). No public spending data are available since 2000 for Uzbekistan. In Mongolia, education expenditures were 5 percent of GDP in 2005 (World Bank, 2010). The drops in spending on public education as a percent of GDP in both countries can attributed to the dramatic drop in funding from the Soviet Union, hyper-inflation during the mid-1990s, and decreases in economic output related to restructuring of the economy.

Enrollment rates in primary and secondary education decreased in both Mongolia and Uzbekistan during the first part of the 1990 s, but stabilized by 2000 and rose to virtually 100 percent in primary education. Progression to secondary school continues to be very strong in both countries at more than 95 percent (World Bank, 2010). The major difference between the two countries is at the tertiary level where, by 2008 , there was a 58 percent gross enrollment rate for females and a 37 percent gross enrollment rate for males in Mongolia. In Uzbekistan, the gross enrollment rates in tertiary education for 2008 were just 8 percent for females and 12 percent for males (World Bank, 2010). In keeping with their different patterns of economic development, permitting private sector expansion expanded higher education opportunities in Mongolia. In Uzbekistan, there was very limited and controlled private sector expansion along with slow growth of government resources that could be invested in higher education (ADB 2004).

\section{Education Management and Monitoring of Policy Implementation}

The Uzbekistan system of education management has remained largely centralized and largely intact. The pre-existing management structure includes at the central government level: the Republican Commission, the Cabinet of Ministers, the Ministry of Public Education, the Ministry of Higher and Secondary Specialized Education, the Center for Secondary Specialized and Vocational Education. At the regional level the 
educational management structure includes: Local State Administration Bodies (khokimiyats), Regional Departments for Secondary Specialized and Vocational Education, and Regional Public Education Management Bodies. At the institutional level the education management structure includes ministries and offices, which have educational institutions.

The only change to the education management structure is the addition of the Trustee and Supervisory Bodies at the bottom of the hierarchy. Trustee and Supervisory Bodies consist of representatives of founder organizations, local authorities, businesses, public organizations, foundation and sponsors has been added to the pre-existing management structure. The function of the Trustee and Supervisory Bodies is to provide support to educational institutions at the local level (Seitkhalilov et al. 2002).

The Mongolian Parliament monitors the implementation of new education laws and policies, the Government is in charge of implementation, and the Ministry of Education, Culture and Science (MECS) is responsible for the implementation of national polices, programs, and educational standards. In local areas, national polices are implemented through local governors of aimags (provinces), soums (towns), and city districts. The coordination and implementation of education law is done by the governors (Batrinchin et al. 2002).

\section{Information Flows}

In Uzbekistan, collection of educational statistics is divided into three large blocks: statistical information, information on implementation of government assignments, and special purpose data. Provisions in the Law on State Statistical Information requires that reliable and comprehensive information be submitted from enterprises and institutions to the appropriate authority by set dates. Education statistics includes the number of pupils by level of education, type of training, educational materials used, and technical and human resources.

Statistics are collected on more than 20 forms that are filled out by the educational institutions, and passed to the appropriate next level ministry which develop master files for the State Statistical Department of the Ministry of Macroeconomics and Statistics. Information in Uzbekistan seems to flow well from the bottom-up, but not as well top-down (Seitkhalilov et al. 2002). The central government acquires statistical information about education in Uzbekistan, but this information tends not to be shared outside of the certain departments in the government.

The Mongolian Ministry of Education, Culture and Science (MECS) collects statistics from 16 different standard forms sent on diskette or by email twice a year. The complete cycle of collection, summarizing, revisions, analysis and adjustment takes 1-2 months. Information flows remain from bottom-up. Information is gathered at the local level by Education and Culture Centers (ECC), which are the basic local education management information system (EMIS) units and one of their primary functions is ensuring coordination between local government and national administrative organizations. Information is gathered from the local education institutions by the ECC, which then summaries the information and sends in the MECS. Information is used in education policy making, but reliability of information is still sometimes in question, making it difficult to asses with great accuracy the impact of previous education policies. Information is not just made available to decision makers, but also to students, teachers and parents in the form of published reports on education. Unsummarized statistics are rarely made available to persons outside the MECS (Batrinchin et al. 2002).

\section{Monitoring of Education Policy}

The NPPT in Uzbekistan gave responsibility and authority for monitoring and evaluating the education reforms to the Republic Commission, the top of the hierarchy of education management. Two working groups, the Main Working Group (MWG) and the Territorial Working Groups Monitoring (TWGM), are the organizational structure for monitoring educational reforms. The TWGMs are to collect timely information on education reform, submit regular reports to the MWG, carry out surveys and expert appraisals on the education reforms implemented in the different regions of the county, and develop analytical reports as assigned by the MWG to meet the needs of the Cabinet of Ministers. The MWG operates under the Cabinet of Ministers and is to improve monitoring studies and carry out expert appraisal of government assignments on NPPT implementation (Seitkhalilov et al. 2002).

The Ministry of Education, Culture and Science (MECS) in Mongolia set up a new Monitoring and Evaluation Department in 1997. The department is to monitor the implementation of government laws, policies and objectives; and enforce the rules and regulations within the education sector by assessing the evaluating outputs of implementation. The department monitors education through a set of internationally accepted indicators, although the documents do not mention or explain the indictors.

With education decentralization, monitoring and evaluation functions were transferred to the local level. However, lack of capacity at the local level made the decentralization of monitoring and evaluation problematic. In order to improve capacity at the local level, the Economic, Monitoring and Evaluation Department of MECS conducted training focusing on the quality and 
development of assessment tools for primary and secondary education compatible with international practices (Batrinchin et al. 2002).

\section{Education Financing}

Financing for education and for teaching materials and equipment is a stated priory for Uzbekistan. Basic principles for developing new financial and economic mechanisms are laid out in the NPPT, but they seem not to have been implemented. Multichannel financing of personnel training and the development of private institutions are envisioned in the NPPT, but have not been implemented (Seitkhalilov et al. 2002).

Increased migration from rural areas to urban areas in Mongolia has caused some urban schools to be filled over capacity, while some rural schools suffer from shortages of students. This is a principle consideration when funding schools and Mongolia has begun funding based on students rather than capacity. The country case study states that the distance between the school and the central urban areas has become the main criterion for budget allocation rather than the capacity of the individual school. This change in financing mechanism encourages schools to increase enrolment to meet their full capacity, decrease dropout rates and increase interest in the effort in non-formal education services (Batrinchin et al. 2002).

\section{Education and Employment Linkages}

In both countries, the match between education and the market is poor due to limited data about emerging labor market and lack of up-to-date training programs, including a lack of fit between educated specialists and the demand from different economic sectors. In Uzbekistan in 1999, 73 percent of all tracked vocational education graduates were employed, but only 60 percent of those employed made use of their specialized training (Seitkhalilov et al. 2002). In both countries, it is increasingly important to develop the capacity for collecting accurate regional data on labor market demand for individuals over the next 5-10 years and to regularly monitor the labor market in order to develop more effective and productive training.

In both countries, there continue to be poor linkages between tertiary education and the labor market. Too many students are studying business, accounting, finance, law, computing and foreign languages and are not finding jobs in their area of study after graduation while employers in other areas of the economy go begging for applicants.

\section{A Sector-Wide Framework for Education Reform}

Education reform is a complex process, with many agencies and individuals involved. To illustrate this complexity, Figure 1 (Weidman 2001) provides a general framework based on a comprehensive, sector-wide conception of education reform. The dotted lines around the intersecting ellipses are intended show flexible rather than fixed boundaries between agencies and individuals in order to reflect interactive processes and variations in influence. In the center of the figure is Ministries of Education, generally the lead government agency in both planning and development of educational reform initiatives.

The left and right parts of Figure 1 represent the major actors in the educational reform process, both external funders (donor agencies) and participants (country stakeholders). Donor agencies (including development banks and country governments) work with relevant ministry officials in setting priorities for funding, often including officials in related ministries (e.g., Finance, Labor, Social Welfare, etc.) along with representatives of the executive branch of government in negotiations for grants and loans. In most types of funding (e.g., grants, loans, etc.), donors tend to expect some type of contribution from the receiving government such as office space, supplies, transport, local counterparts, etc.

Figure 1. Framework for Educational Reform in Developing Countries

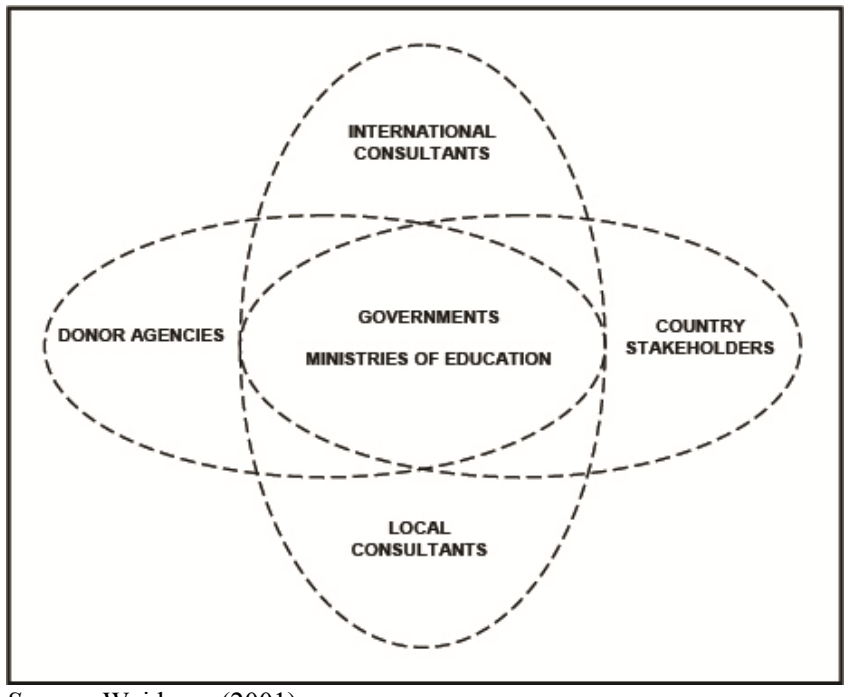

Source: Weidman (2001).

The top and bottom parts of Figure 1 show the two primary groups of experts who provide technical inputs to reform initiatives, including preparation and submission of reports to the government and donor agencies. Both international and local 
consultants are chosen on the basis of the fit between their expertise and the qualifications required for a particular reform. Selection may be done either through direct recruitment of specific individuals or through offering of tenders by the government and/or the donor agency. Local consultants are generally citizens of the host country, selected for their specific expertise as it relates to reform requirements and knowledge of the national educational system.

When international consultants are not conversant in the language(s) of the host country, local consultants often assist with interpretation at meetings and of necessary government documents (though translation of longer documents, regulations, etc. is preferably done on a contract basis). It is also important for project consultants to have ministry counterparts who are at least partially released from their normal duties to provide assistance with the identification of documents and data required for various reform initiatives. There are often periodic meetings among the key actors in policy development and reform development, sometimes including organizing a national conference to discuss preliminary recommendations (Weidman 2001).

\section{Discussion}

Based on the comparisons of educational reforms in Mongolia and Uzbekistan discussed in these recent ADB case studies of education reform (Seitkhalilov et al. 2002; Batrinchin et al. 2002; ADB 2004) as well as the general framework shown in Figure 1, a few observations can be made. Although both countries state their commitment to transitioning from a single-party and commandeconomy to a liberal democracy and a free-market, with education playing a role in each country's transition, Mongolia has made such reforms while Uzbekistan remains a single-party state with strong economic controls. Perhaps a good name for this might be the "chameleon effect," where countries borrowing money from a particular funding organization frame their reforms in terms of the ideas about society from the funding organization, even when they don't actually reflect the reforms or what is actually occurring within the country. It would be interesting to see if the chameleon effect found in these case studies on education in Mongolia and Uzbekistan could be generalized to more countries though a systematic comparison of case studies from more countries in the region (Weidman et al. 2003).

A second observation that can be made is that the education reform process within each country mirrors the political situation of each country. As pointed out by Marc Cohn (2002), a Senior Education Specialist for the ADB, the differences in how education is reformed is indicative of how each country views society and the role education plays in a period of rapid transition.
Mongolia, with a few peaceful political transitions through national elections since 1991, has had a more transparent, participatory and decentralized educational reform process. Mongolia has involved major non-governmental as well as local community stakeholders and been transparent in its use of sector analysis and master planning in the educational reform process (Weidman 2001). Education reform was decentralized through the devolution of authority in some areas of education to the local and institutional level. Finally, Mongolia distanced itself from Russia and aligned itself with the West in seeking to attract donor support for education reform, successfully obtaining funds from both bilateral (US, Germany, Canada, Japan, Korea) and multi-lateral (EU, World Bank, ADB) sources (Weidman 2001).

After the fall of the Soviet Union, political elites seized power in Uzbekistan and have not made many political or economic reforms (Freedom House 2009). The president elected in the immediate post-transition period is still in office 20 years later. Uzbekistan's educational reforms have been centralized, autocratic and lack transparency. Few outside the executive aparat (primarily the president, the Cabinet of Ministers, and a few trusted advisers) of the government have been involved in the decisions about educational reforms. The educational structures remain highly hierarchical, with policy reform being developed by the president and Cabinet of Ministers and implemented in a topdown manner. The education policy process lacks transparency, with very limited involvement of key stakeholders. There is no independent judiciary and civil society barely exists (Freedom House 2009). Recent political alignments have shifted away from the United States (which has a military base there) to Russia as tensions mount on its borders with Afghanistan and Kyrgyzstan.

Thus, despite similar political, economic, and educational foundations prior to transition, Uzbekistan and Mongolia have taken very different paths to educational reform. It remains to be seen what the long-term results will be in each country, both decidedly "works in progress."

\section{References}

Asian Development Bank (ADB). 2004. Education Reforms in Countries in Transition: Policies and Processes. Six Country Case Studies Commissioned by the Asian Development Bank in Azerbaijan, Kazakhstan, Kyrgyz Republic, Mongolia, Tajikistan, and Uzbekistan. Manila, Philippines: ADB. Available online at: http://www.adb.org.

ADB. 1992. Mongolia: A Centrally Planned Economy in Transition. New York: Oxford University Press. 
Batrinchin, Pagma, Nerendoo Nergui, Damba Monkhor, Tsendjav Jargalmaa, Altangerel Hajidsuren, and John C. Weidman. 2002. Mongolia Country Study. RETA No. 5946-REG: SubRegional Cooperation in Managing Education Reforms. Manila, Philippines: ADB.

Center for Economic Research. 1997. Uzbekistan Human Development Report, Chapter 1, "Building Social Cohesion in the Transition Period.” Bishkek, Kyrgyz Republic: Center for Economic Research. Available online at: http://www.cer.uz/en/publications/155.

Central Intelligence Agency (CIA). 2010a. World Factbook: Mongolia. Available online at: http://www.cia.gov.

CIA. 2010b. World Factbook: Uzbekistan. Available online at: http://www.cia.gov.

Cohen, Marc. 2002. "Governance in Education Reforms." Paper presented at Policy Conference conducted in conjunction with Asian Development Bank RETA No. 5946-REG: SubRegional Cooperation in Managing Education Reforms. Bishkek, Kyrgyz Republic, 16-17 October 2002.

Dawisha, Karen, and Bruce Parrott, eds. (1997). Conflict, Cleavage, and Change in Central Asia and the Caucasus. New York: Cambridge University Press.

Freedom House. 2009. Nations in Transit 2009: Uzbekistan Report and Tables. Washington, DC: Freedom House. Available online at: http://www.freedomhouse.org.

Karimov, Islam. 1998. Uzbekistan on the Threshold of the Twenty-First Century: Challenges to Stability and Progress. New York: St. Martin's Press.

Peimani, Hooman. 2002. Failed Transition, Bleak Future? War and Instability in Central Asia and the Caucasus. Westport, CT: Praeger.

Polyzoi, Eleoussa, Michael Fullan and John P. Anchan, eds. 2003. Change Forces in Post-Communist Eastern Europe: Education in Transition. New York: RoutledgeFalmer.

Seitkhalilov, Edem, Rakhmat Abdukarimov, Noila Azizkhodjaeva, Svetlana Annamouratova, Gulandom Alimova and Zulfiya Tukhtakhodjaeva, and John C. Weidman. 2002. Uzbekistan Country Study. RETA No. 5946-REG: SubRegional Cooperation In Managing Education Reforms. Manila, Philippines: ADB.

Weidman, John C. 2001. "Developing the Mongolia Education Sector Strategy 2000-2005: Reflections of a Consultant for the Asian Development Bank." Current Issues in Comparative Education 3 (2). Available online at: http://www.tc.columbia.edu/cice.

Weidman, John C., and Regrusen Bat-Erdene. 2002. "Higher Education and the State in Mongolia: Dilemmas of Democratic Transition." In Higher Education in the Developing World:
Changing Contexts and Institutional Responses, ed. David W. Chapman and Ann E. Austin. Westport, CT: Greenwood Press. Weidman, John C., Regsuren Bat-Erdene, Ochir Gerel, and Dendev Badarch. 1997. "Mongolia." In Asian Higher Education: An International Handbook and Reference Guide, ed. Gerard A. Postiglione and Grace C.L. Mak. Westport, CT: Greenwood Press.

Weidman, John C., David W. Chapman, Marc Cohen, and Macrina C. Lelei. 2003. "Access to Education in Five Newly Independent States of Central Asia and Mongolia: A Regional Agenda." In Challenges for Education in Central Asia, ed. Stephen P. Heyneman and Alan J. DeYoung. Greenwich, CT: Information Age Publishing.

World Bank. 2010. World Development Indicators. Washington, DC: World Bank. 